\title{
Gold Mineralization in the Kyaikhto District, Mon State, Southern Myanmar
}

\author{
Myo Kyaw Hlaing ${ }^{1,2}$, Aung Zaw Myint ${ }^{2}$, Thomas Tindell1, May Thwe Aye ${ }^{2}$ \\ ${ }^{1}$ Department of Earth Resources Engineering, Kyushu University, Fukuoka, Japan \\ ${ }^{2}$ Department of Geology, University of Yangon, Yangon, Myanmar \\ Email: ^myo@mine.kyushu-u.ac.jp
}

How to cite this paper: Hlaing, M.K., Myint, A.Z., Tindell, T. and Aye, M.T. (2019) Gold Mineralization in the Kyaikhto District, Mon State, Southern Myanmar. Open Journal of Geology, 9, 29-42. https://doi.org/10.4236/ojg.2019.91003

Received: December 26, 2018

Accepted: January 19, 2019

Published: January 22, 2019

Copyright $\odot 2019$ by author(s) and Scientific Research Publishing Inc. This work is licensed under the Creative Commons Attribution International License (CC BY 4.0).

http://creativecommons.org/licenses/by/4.0/

\section{cc) (i) Open Access}

\begin{abstract}
The Kyaikhto gold district is located within the Slate Belt and Mogok Metamorphic Belt of Southern Myanmar. The study area is covered by Carboniferous to Lower Permian metasedimentary rocks consisting of slate, phyllite, and schist of the Mergui Group, intruded by later igneous rocks. Four gold occurrences have been identified in the Kyaikhto district: the Kunzeik in the north, Zibyaung, and Thae Phyu Chaung in the center and Meyon in the south. Gold mineralization in the Kyaikhto district is associated with sheeted, stockwork, dissemination, and sulfide-bearing quartz veins. Ore minerals recognized include sphalerite, galena, chalcopyrite, molybdenite and pyrite with minor native gold and electrum. Two types of fluid inclusions were examined in the quartz samples of the Kunzeik and Zibyaung-Type A: aqueous carbonic fluid inclusions and Type B: aqueous fluid inclusions. At the Kunzeik, Type A fluid inclusions homogenize at temperatures from $296^{\circ} \mathrm{C}$ to $376^{\circ} \mathrm{C}$ with low salinities (1.6 - $4.6 \mathrm{wt} \% \mathrm{NaCl}$ equivalent). The homogenization temperatures of Type B fluid inclusions in vein quartz range from $246^{\circ} \mathrm{C}$ to $312^{\circ} \mathrm{C}$, with salinities of between 1.2 and $10.7 \mathrm{wt} \% \mathrm{NaCl}$ equivalent. In the Zibyaung, the homogenization temperatures of Type A inclusions vary from $305^{\circ} \mathrm{C}$ to $378^{\circ} \mathrm{C}$, with salinities from 4.6 to $9.6 \mathrm{wt} \% \mathrm{NaCl}$ equivalent. The homogenization temperatures of Type $\mathrm{B}$ fluid inclusions mainly range from $242^{\circ} \mathrm{C}$ to $298^{\circ} \mathrm{C}$, with salinities from 0.9 to $11.8 \mathrm{wt} \% \mathrm{NaCl}$ equivalent. These characteristics of fluid inclusions are similar to those of orogenic gold mineralization systems.
\end{abstract}

\section{Keywords}

Mineralization, Fluid Inclusion, Kyaikhto District, Southern Myanmar

\section{Introduction}

Gold occurrences in Myanmar are distributed in N-S trending mineral belts that 
extend from the Tatlet in the north to the Meyon in the south, including numerous localities throughout the Slate Belt of the Eastern Highlands [1] (Figure 1). Gold deposits occur in the form of auriferous quartz veins throughout the Phayaung Taung, Modi Taung, Nankwe, Shwekyin, and Kyaiktho areas in the Slate Belt (Figure 1). The Kyaikhto gold district is situated at the southern end of the Slate Belt and Mogok Metamorphic Belt where gold deposits are hosted by the granitic rocks and Carboniferous to Lower Permian metasedimentary rocks of the Mergui Group metamorphosed to greenschist facies [2] [3] (Figure 1). This belt of gold mineralization was first reported by [1], as gold deposits of Slate-hosted mesothermal quartz-gold veins (orogenic gold deposit) (Figure 1). The Slate Belt was intruded by numerous granitic rocks that host tin and

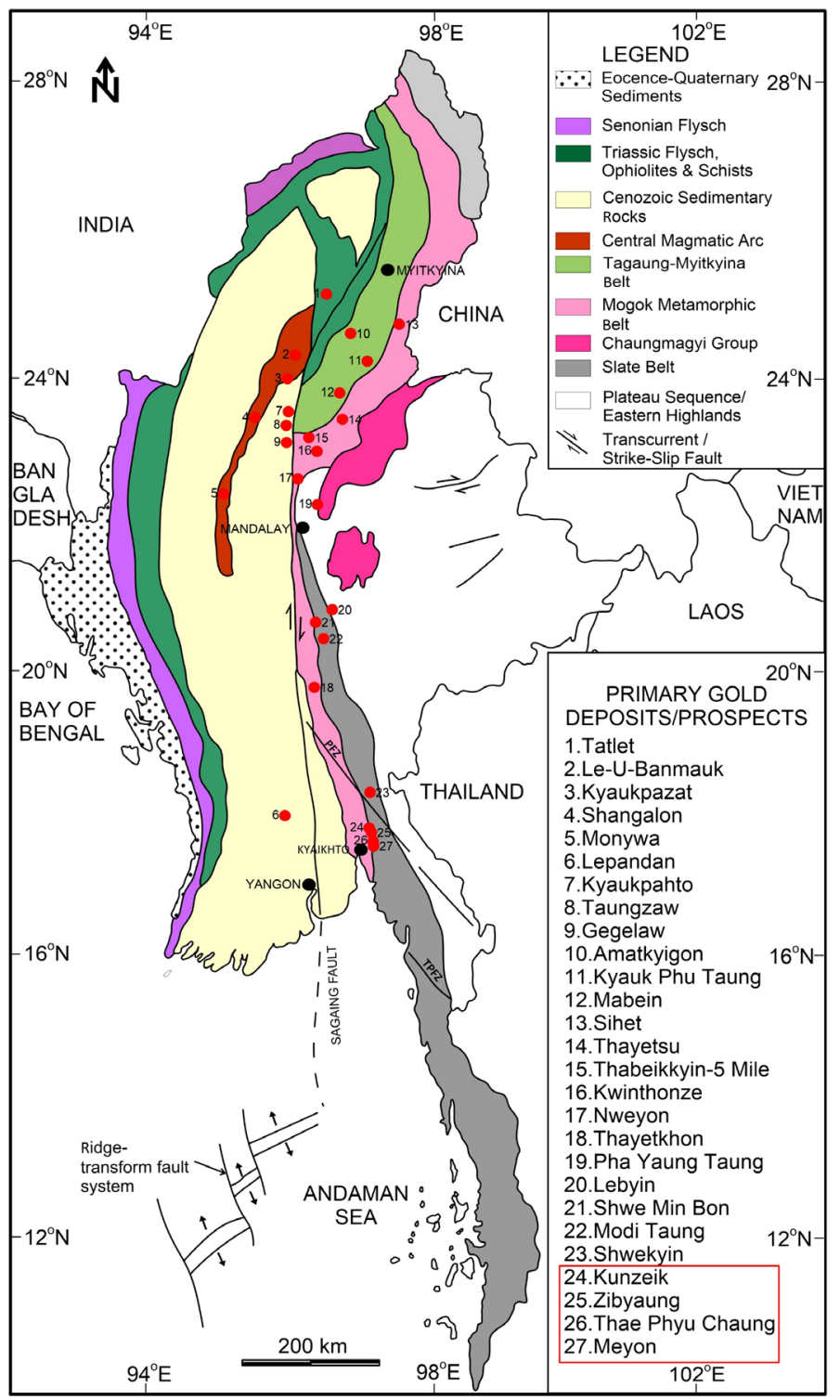

Figure 1. Major structural belts and location of major gold deposits and prospects in Myanmar (Modified after [1] [8]), PFZ, Papun Fault Zone, TPFZ, Three Pagodas Pass Fault. 
tungsten deposits of the Western Granite Province, part of the Southeast Asian Granitoid Tin Belt [4] [5]. This belt contains narrow but high-grade orogenic quartz-gold veins discovered almost 20 years ago [6]. [7] suggested that gold and sulfide-bearing veins in the Kyaikhto district were "mesothermal vein deposits". However, there is no detailed research work about gold mineralization in the Kyaikhto district and ore genesis is poorly understood. In this paper, we present the results from geological, mineralogical and fluid inclusion studies of gold mineralization in the Kyaikhto district. The main purpose of this study is to determine the genesis of ore-formingfluid and to constrain the formation of gold mineralization in the Kyaikhto district.

\section{Regional Geologic Setting}

The gold mineralization in the Kyaikhto district is located between the southeastern part of the Indo-Burma Ranges (Burma Plate) and the southwestern part of the Indo-China Block (the southern part the Eastern Highlands) (Figure 1 and Figure 2). Geological structures at the southwestern margin of the Eastern Highlands are complicated due to the presence of older and some younger active strike-slip faults [9] [10] [11]. The gold mineralization in the Kyaikhto district is located close to the Sagaing Fault, a major young active strike-slip fault trending

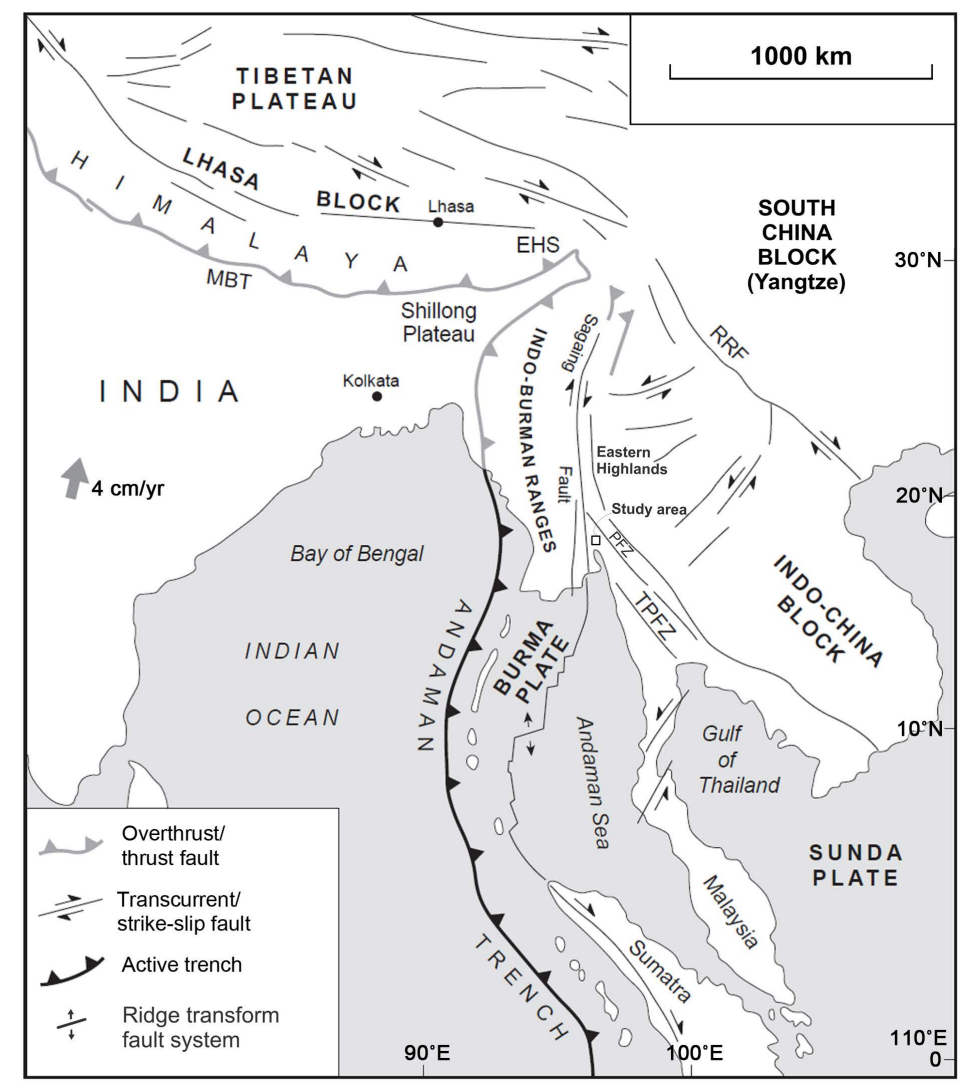

Figure 2. Regional tectonic setting of Myanmar and its surrounding area (Modified after [6]). EHS, Eastern Himalayan Syntaxes; MBT, Main Boundary Thrust; RRF, Red River Fault; PFZ, Papun Fault Zone; TPFZ, Three Pagodas Pass Fault. 
N-S about $32-40 \mathrm{~km}$ to the west (Figure 2). The gold mineralization in the Kyaikhto district is underlain by metasedimentary rocks and granitic rocks. The metasedimentary rocks belong to the Mergui Group of Carboniferous to Lower Permian age [12], striking N-S. The Kyaikhto gold district seems to have been subjected to dynamic deformation and conjugate local faulting in addition to being subjected to a large amount of heat from the batholiths to the east [7]. The age of mineralization of gold deposit is suggested to be Upper Cretaceous to Paleogene and may have been associated with deformation and metamorphism along the Papun Fault Zone [13] [14] (Figure 2).

\section{Deposit Geology}

Four mineralized zones have been identified from south to north as the Kunzeik, Zibyaung, Thae Phyu Chaung and Meyon (Figure 3). Gold mineralization in the

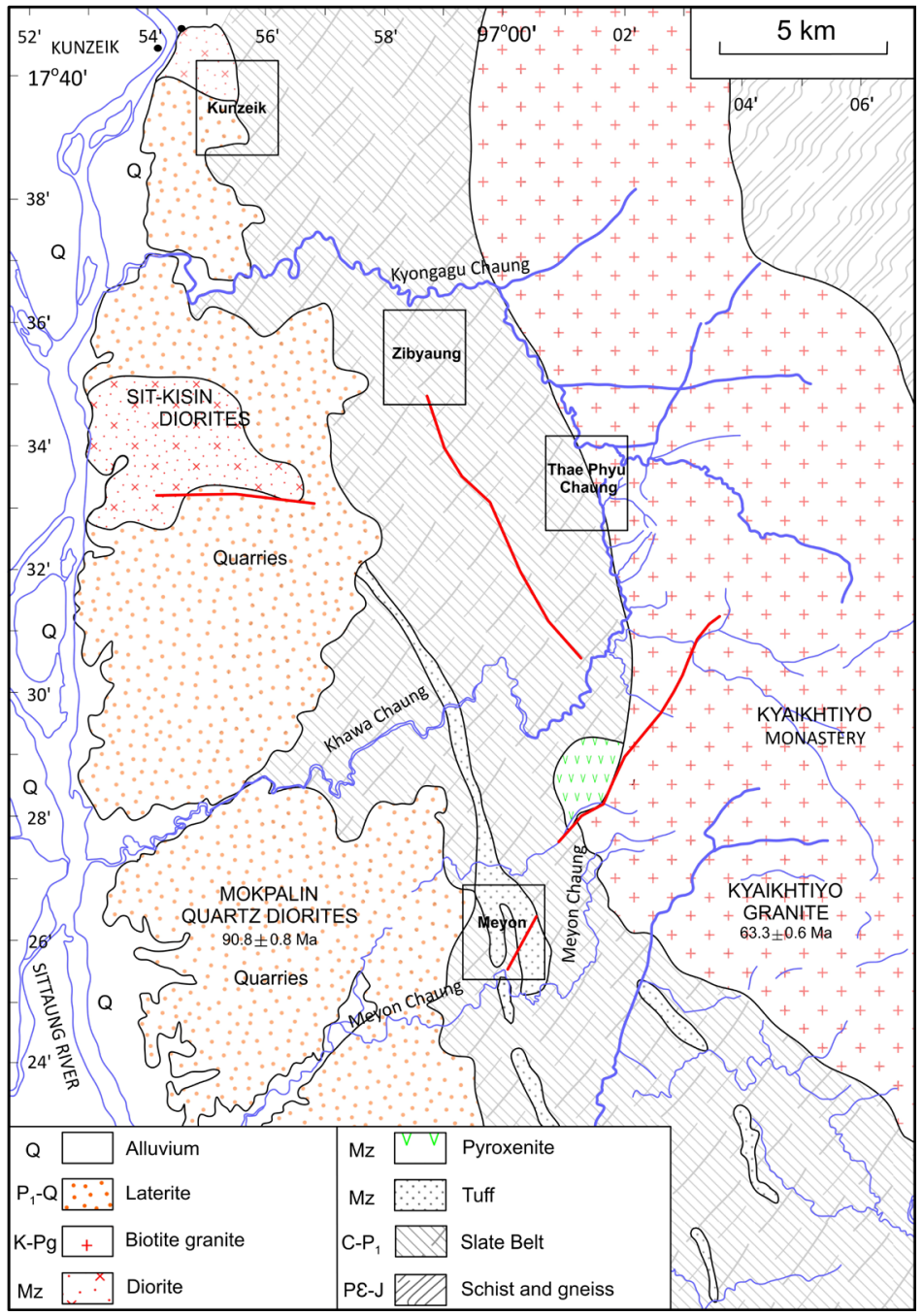

Figure 3. Geological map of the Kyaikhto gold district. Red lines are faults (Modified after [3] [7]. Abbreviations: $\mathrm{Q}=$ Quaternary, $\mathrm{P}_{1}-\mathrm{Q}=$ Lower Pliocene to Quaternary, $\mathrm{K}-\mathrm{Pg}=$ Cretaceous to Paleogene, $\mathrm{Mz}=$ Mesozoic, $\mathrm{C}-\mathrm{P}_{1}=$ Carboniferous to Lower Permian, $\mathrm{P} \varepsilon-\mathrm{J}=$ Precambrian to partly Jurassic. 
Kyaikhto district occurred as sheeted veins, massive veins, network veinlets, stockworks, and dissemination. The general orientation of quartz veins lies NNE-SSW, with some veins trend NW-SE. Mineralization in the Kyaikhto gold district is predominately hosted by biotite granite, biotite granodiorite and metasedimentary rocks of Mergui Group (Figure 3). The granitic rocks in this district can be correlated to the Mokpalin quartz diorite and the Kyaikhtiyo granite that have the LA-ICP-MS zircon U-Pb ages of $90.8 \pm 0.8 \mathrm{Ma}$ and $63.3 \pm 0.6 \mathrm{Ma}$, respectively [3] (Figure 3). The Mergui Group consists of low-grade metamorphic rocks, principally slate, phyllite, and schist. The metamorphic grade of these rocks is greenschist facies, characterized by a mineral assemblage of epidote, biotite, muscovite, chlorite and sericite. Locally, fine-grained pyrite crystals are disseminated in the slate, phyllite, and schist. Some $10 \mathrm{~km}$ to the southwest, several primary and alluvial gold workings are operated in serpentinite, exposed beneath the lateritic cover.

\section{Materials and Analytical Methods}

Thirty-five polished sections were prepared to determine ore and gangue minerals from the Kunzeik, Zibyaung, Thae Phyu Chaung, and Meyon and examined with a NIKON ECLIPSE LV100N POL petrographic microscope. Five doubly polished thin sections for fluid inclusion analysis were selected from the Kunzeik and Zibyaung. Microthermometric measurements were carried out using a Linkam-THMS600 heating-freezing stage equipped on a NIKON ECLIPSE LV100N POL petrographic microscope. The heating/freezing rate was generally $0.2^{\circ} \mathrm{C}-$ $5.0^{\circ} \mathrm{C} / \mathrm{min}$ but was $<0.2^{\circ} \mathrm{C} / \mathrm{min}$ near a phase transition. The uncertainties for the measurements are $\pm 0.5^{\circ} \mathrm{C}, \pm 0.2^{\circ} \mathrm{C}$ and $\pm 2.0^{\circ} \mathrm{C}$ for runs in the range of $-120^{\circ} \mathrm{C}$ to $-70^{\circ} \mathrm{C},-70^{\circ} \mathrm{C}$ to $100^{\circ} \mathrm{C}$, and $100^{\circ} \mathrm{C}$ to $600^{\circ} \mathrm{C}$, respectively. Ice melting temperatures were observed at a heating rate of less than $0.1^{\circ} \mathrm{C} / \mathrm{min}$ and homogenization temperatures at the rate of $\leq 1^{\circ} \mathrm{C} / \mathrm{min}$. The fluid inclusions were classified by the criteria of [15]. Total salinities of $\mathrm{NaCl}-\mathrm{H}_{2} \mathrm{O}$ inclusions were calculated from the final melting temperatures of ice using the equation by [16]. The salinities of $\mathrm{CO}_{2}$-bearing fluid inclusions were calculated using the melting temperatures of clathrate [17]. All analyses were undertaken at the Department of Earth Resources Engineering, Kyushu University.

\section{Results}

\subsection{Mineralization}

\subsubsection{Kunzeik}

Gold mineralization in the Kunzeik is hosted by the biotite granite, biotite granodiorite, and metasedimentary rocks. The style of mineralization includes stockwork, dissemination and quartz-sulfide veins. Minor fine-grained pyrite and chalcopyrite are irregularly dispersed throughout the veins (Figure 4(a) and Figure 4(b)). The biotite granodiorite and slate are composed of sericite due to intense phyllic alteration. Molybdenite occurs as disseminated grains in biotite 

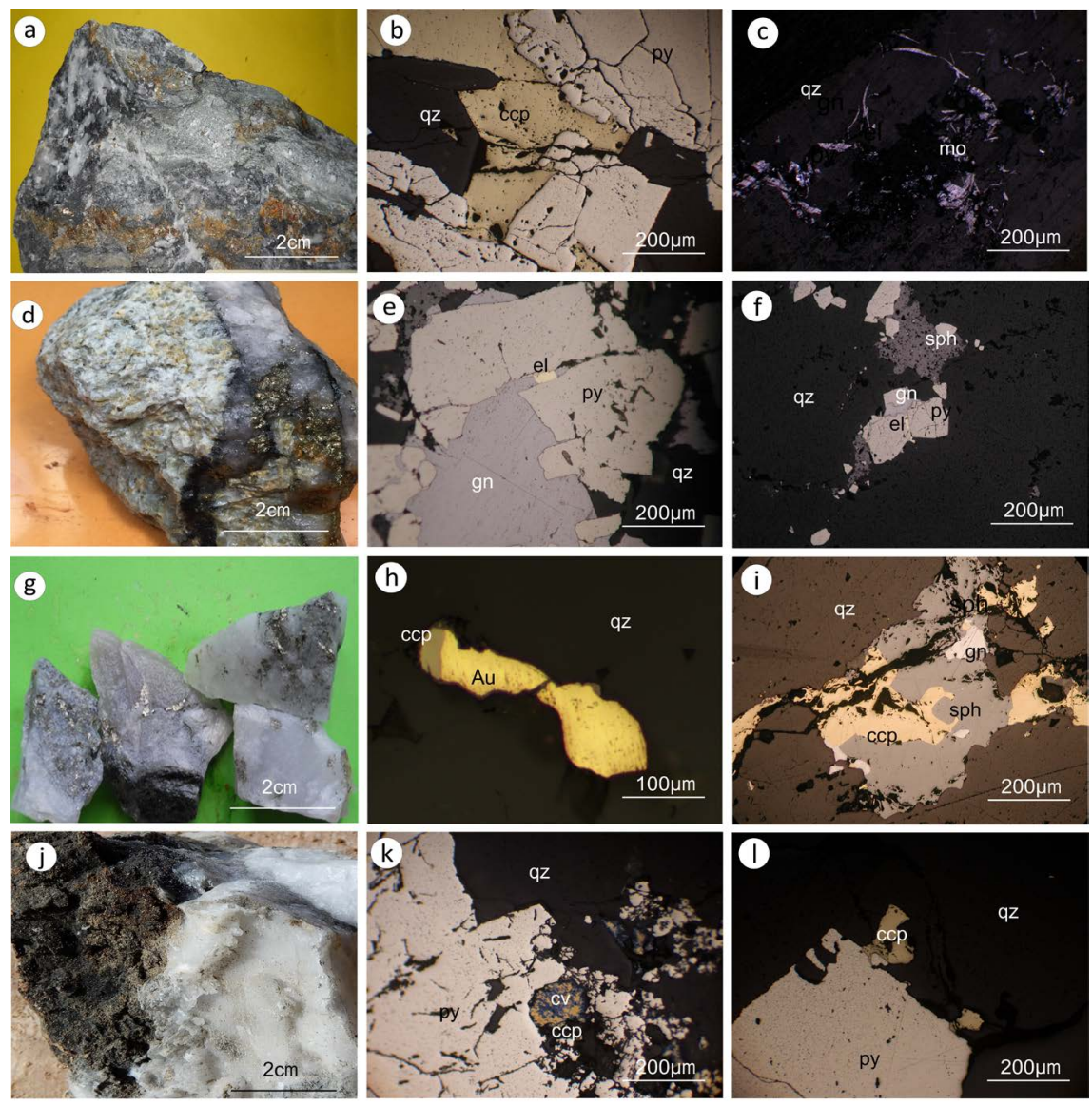

Figure 4. (a) Photograph ((a), (d), (g), (j)) and photomicrographs ((b), (c), (e), (f), (h), (i), (k), (l)) showing ore and ore minerals from the Kyaikhto gold district: (a) Quartz-sulfide vein from the Kunzeik; (b) Fractured pyrite replaced by chalcopyrite in quartz vein from the Kunzeik; (c) Molybdenite dispersed in biotite granite from the Kunzeik; (d) Quartz-sulfide vein from the Zibyaung; (e, f) Electrum associated with galena, sphalerite and euhedral pyrite in the quartz-sulfide vein from the Zibyaung; (g) Quartz-sulfide vein from the Thae Phyu Chaung; (h) Native gold associated with chalcopyrite in the quartz-sulfide vein from the Thae Phyu Chaung; (i) Sphalerite and chalcopyrite enclosed within galena in the quartz-sulfide vein from the Thae Phyu Chaung; (j) Quartz-sulfide vein from the Meyon; (k) Pyrite and chalcopyrite enclosed within covellite in the quartz-sulfide vein from the Meyon; and (l) Pyrite associated with chalcopyrite in the quartz-sulfide vein from the Meyon. Abbreviations: $\mathrm{py}=$ pyrite, gn = galena, $\mathrm{cv}=\mathrm{co}-$ vellite, $\mathrm{ccp}=$ chalcopyrite, $\mathrm{sph}=$ sphalerite, $\mathrm{mo}=$ molybdenite, $\mathrm{qz}=$ quartz, $\mathrm{el}=$ electrum and $\mathrm{Au}=$ native gold.

granite (Figure $4(\mathrm{c})$ ). The irregular network of small quartz veinlets cut the biotite granodiorite forming stockwork mineralization.

\subsubsection{Zibyaung}

In the Zibyaung, the quartz-sulfide vein strikes northwest and dips steeply to the north (Figure $4(\mathrm{~d})$ ). It is mainly hosted by slate and schist. The biotite granodiorite suffered from an earlier propylitic (chlorite) alteration followed by silicification and later sericitization. Electrum is present as an infill mineral in pyrite and associated with sphalerite and galena (Figure 4(e) and Figure 4(f)). Sphale- 
rite forms as a fissure filling mineral within pyrite. Galena occurs as fine to medium-sized grains filling cracks in pyrite and sphalerite.

\subsubsection{Thae Phyu Chaung}

Gold mineralization in the Thae Phyu Chaung is characterized by white to milky sheeted quartz veins that contain Au-Ag-Te-Bi minerals (Figure 4(g)). Sphalerite-rich ores are the most common in this deposit, associated with massive chalcopyrite and galena. Pyrite ranges from medium to coarse-grained, anhedral aggregates replacing and infilling grain boundaries of chalcopyrite and, to a lesser extent, sphalerite. Native gold is mainly associated with chalcopyrite and galena or located at the boundary between chalcopyrite grains (Figure $4(\mathrm{~h})$ and Figure 4(i)).

\subsubsection{Meyon}

Gold mineralization in the Meyon is characterized by a shear-hosted quartz-sulfide vein (Figure $4(\mathrm{j})$ ). The quartz-gold vein is hosted within an intensely deformed sedimentary sequence comprising sandstone and carbonaceous mudstones. The quartz vein strikes NNE and dips steeply to the east. It has a known strike length of $235 \mathrm{~m}$ and an average thickness of $1.5 \mathrm{~m}$. The enclosing shear zone has an average width of $4 \mathrm{~m}$. Some thin stockwork quartz veins in the sedimentary rock also carry gold. Strongly sheared and brecciated nature of the host rocks occurs adjacent to the veins. Post-mineralization deformation caused minor offsets of the vein. Brecciation and fracturing of the quartz vein have produced excellent sites for gold deposition remobilized by supergene processes. Chalcopyrite is associated with pyrite and covellite. Covellite occurs as a secondary mineral of chalcopyrite (Figure 4(k) and Figure 4(1)).

\section{Fluid Inclusions Studies}

\subsection{Fluid Inclusion Petrography}

Fluid inclusions in the quartz from the auriferous quartz veins of the Kunzeik and Zibyaung were examined. Fluid inclusions hosted in granular quartz crystals in veins which were distributed randomly in clusters, and in isolation, were interpreted as primary in origin. Those aligned along micro-fractures in intragranular with growth zones in granular crystals trails were interpreted as secondary or pseudo secondary inclusions based on the classification by [15]. Secondary fluid inclusions in healed fractures were avoided. Examination identified two different types of fluid inclusions: 1) Type A: aqueous carbonic fluid inclusions which have three phases with two components (liquid-liquid-vapor or L-L-V); and 2) Type B: aqueous liquid and vapor inclusions which consist of two phases (liquid-vapor or L-V) (Figures 5(a)-(d)). Fluid inclusions have round to irregular shapes and contain no daughter mineral. Type A fluid inclusions coexist with Type B fluid inclusions and there is no crosscutting relationship between these two groups within the same quartz crystal (Figures 5(a)-(d)). These relationships reveal that two types of fluids were present during the precipitation of 

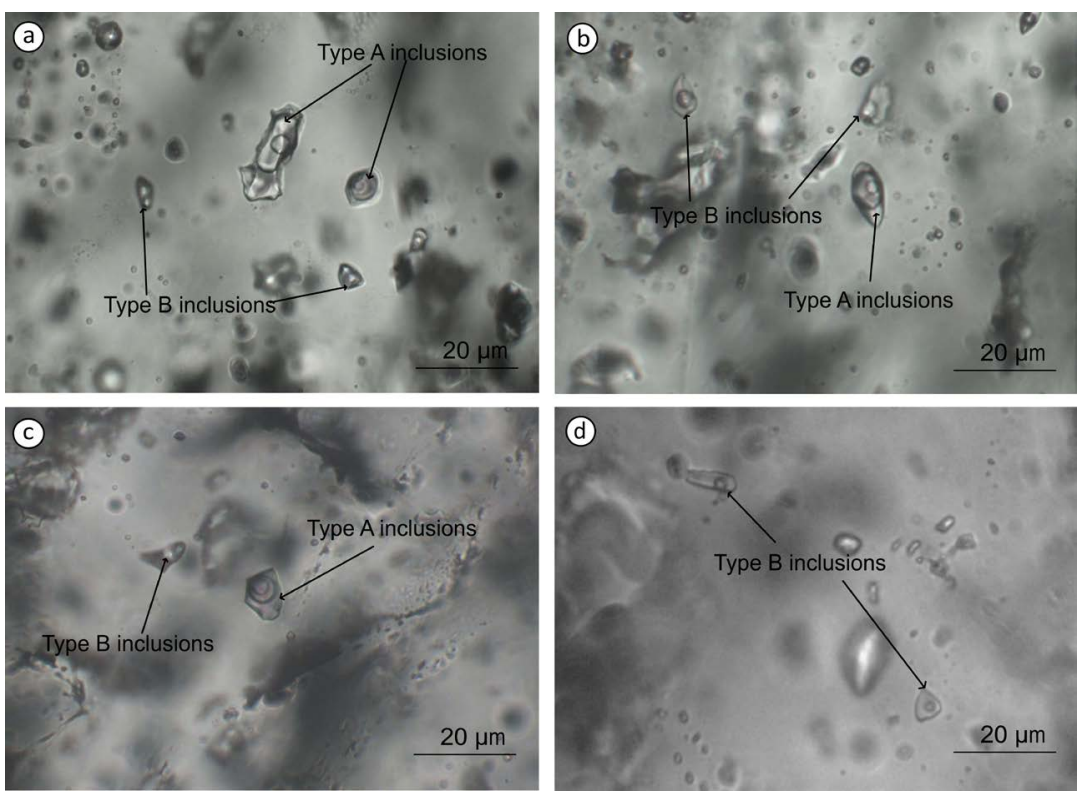

Figure 5. Photomicrographs of fluid inclusions in quartz-sulfide veins at room temperature in plane-polarized light. ((a), (b)) Type A and B fluid inclusions coexisting together within same quartz gain in quartz-sulfide veins from the Kunzeik; (c) Type A and B fluid inclusions in the quartz-sulfide vein from the Zibyaung; and (d) Type B fluid inclusions in quartz-sulfide veins from the Zibyaung.

quartz-sulfide vein in the Kunzeik and Zibyaung. Type A inclusions are exclusively found in the quartz-sulfide vein from the Kunzeik and Zibyaung. Type A fluid inclusions have ellipsoidal or irregular shapes with sizes ranging from 10 to $30 \mu \mathrm{m}$. The sizes of the vapor bubble are up to approximately $50-80 \mathrm{vol} \%$ of the inclusion (Figures 5(a)-(c)). Type B fluid inclusions are very common in quartz grains in quartz-sulfide vein at the Kunzeik and Zibyaung. The Type B fluid inclusions have a sub-rounded, small, elliptical and irregular form, and vary in size from 5 to $20 \mu \mathrm{m}$ in diameter with most between 8 and $15 \mu \mathrm{m}$ (Figure 5(d)). Type B fluid inclusions consist of two phases (liquid-vapor or L-V) containing 10 - 30 vol\% vapor (average 20 - 25 vol\%) (Figure 5(b)).

\subsection{Microthermometry}

The results of fluid inclusion microthermometry are summarized in Table 1.

\subsubsection{Kunzeik}

The $\mathrm{CO}_{2}$ phases of Type A inclusions were totally homogenized to a liquid phase at temperatures $\left(\mathrm{T}_{\mathrm{h}-\mathrm{CO} 2}\right)$ between $28.2^{\circ} \mathrm{C}$ and $31.3^{\circ} \mathrm{C}$, indicating the presence of $\mathrm{NaCl}$. The $\mathrm{CO}_{2}$ melting temperatures $\mathrm{T}_{\mathrm{m}-\mathrm{CO} 2}$ of fluid inclusions range from $-58.2^{\circ} \mathrm{C}$ to $-56.8^{\circ} \mathrm{C}$ similar to, or slightly lower than, the triple point of pure $\mathrm{CO}_{2}\left(-56.6^{\circ} \mathrm{C}\right)[15]$, indicating they are mostly pure $\mathrm{CO}_{2}$, with minor other volatile components [15]. The melting temperatures of clathrates $\left(\mathrm{T}_{\mathrm{m}-\mathrm{cla}}=7.6^{\circ} \mathrm{C}\right.$ $9.2^{\circ} \mathrm{C}$ ) indicates that the salinity of these inclusions is low, about 1.6 to $4.6 \mathrm{wt} \%$ $\mathrm{NaCl}$ equivalent. Total homogenization temperatures $\left(\mathrm{T}_{\mathrm{h}}\right)$ of Type A fluid inclusions range from $296^{\circ} \mathrm{C}$ to $376^{\circ} \mathrm{C}(\mathrm{N}=31)$ (Figure $6(\mathrm{a})$ ). Homogenization 
Table 1. Summary of fluid inclusion types and microthermometric data for fluid inclusions of the Kunzeik and Zibyaung.

\begin{tabular}{|c|c|c|c|c|c|c|c|c|}
\hline Deposit Name & Vein Type & Type & $\mathrm{T}_{\mathrm{m}-\mathrm{CO} 2}\left({ }^{\circ} \mathrm{C}\right)$ & $\mathrm{T}_{\mathrm{m}-\mathrm{cla}}\left({ }^{\circ} \mathrm{C}\right)$ & $\mathrm{T}_{\mathrm{h}-\mathrm{CO} 2}\left({ }^{\circ} \mathrm{C}\right)$ & $\mathrm{T}_{\mathrm{h}}\left({ }^{\circ} \mathrm{C}\right)$ & $\mathrm{T}_{\text {m-ice }}\left({ }^{\circ} \mathrm{C}\right)$ & $\begin{array}{c}\text { Salinity } \\
\text { (wt } \% \mathrm{NaCl} \text { eq.) }\end{array}$ \\
\hline Kunzeik & Quartz-sulfide vein & Type A & $\begin{array}{c}-58.2 \text { to }-56.8 \\
(\mathrm{~N}=31)\end{array}$ & $\begin{array}{l}7.6 \text { to } 9.2 \\
(\mathrm{~N}=22)\end{array}$ & $\begin{array}{c}28.2 \text { to } 31.3 \\
(\mathrm{~N}=31)\end{array}$ & $\begin{array}{c}296 \text { to } 376 \\
(\mathrm{~N}=31)\end{array}$ & & $\begin{array}{l}1.6 \text { to } 4.6 \\
(\mathrm{~N}=22)\end{array}$ \\
\hline \multirow{3}{*}{ Zibyaung } & \multirow{3}{*}{ Quartz-sulfide vein } & Type B & & & & $\begin{array}{c}246 \text { to } 312 \\
(\mathrm{~N}=53)\end{array}$ & $\begin{array}{c}-2.1 \text { to }-7.2 \\
(\mathrm{~N}=28)\end{array}$ & $\begin{array}{c}1.2 \text { to } 10.7 \\
(\mathrm{~N}=28)\end{array}$ \\
\hline & & Type A & $\begin{array}{c}-57.3 \text { to }-56.8 \\
(\mathrm{~N}=11)\end{array}$ & $\begin{array}{c}4.6 \text { to } 7.6 \\
(\mathrm{~N}=7)\end{array}$ & $\begin{array}{l}28.3 \text { to } 30.1 \\
(\mathrm{~N}=11)\end{array}$ & $\begin{array}{c}305 \text { to } 378 \\
(\mathrm{~N}=11)\end{array}$ & & $\begin{array}{l}4.6 \text { to } 9.6 \\
(\mathrm{~N}=8)\end{array}$ \\
\hline & & Type B & & & & $\begin{array}{c}242 \text { to } 298 \\
(\mathrm{~N}=19)\end{array}$ & $\begin{array}{c}-0.5 \text { to }-8.1 \\
(\mathrm{~N}=11)\end{array}$ & $\begin{array}{c}0.9 \text { to } 11.8 \\
(\mathrm{~N}=11)\end{array}$ \\
\hline
\end{tabular}

Notes: $\mathrm{T}_{\mathrm{m}-\mathrm{CO} 2}-$ melting temperature of $\mathrm{CO}_{2} ; \mathrm{T}_{\mathrm{m}-\mathrm{cla}}-$ melting temperature of $\mathrm{CO}_{2}$ clathrate; $\mathrm{T}_{\mathrm{h}-\mathrm{CO} 2}$-partial homogenization temperature of $\mathrm{CO}_{2}$ inclusions; $\mathrm{T}_{\mathrm{h}}$-total homogenization temperature of inclusions; $\mathrm{T}_{\mathrm{m} \text {-ice }}$-final ice melting temperature; $\mathrm{wt} \% \mathrm{NaCl}$ eq., weight percent $\mathrm{NaCl}$ equivalent; $\mathrm{N}=$ total number of fluid inclusions.
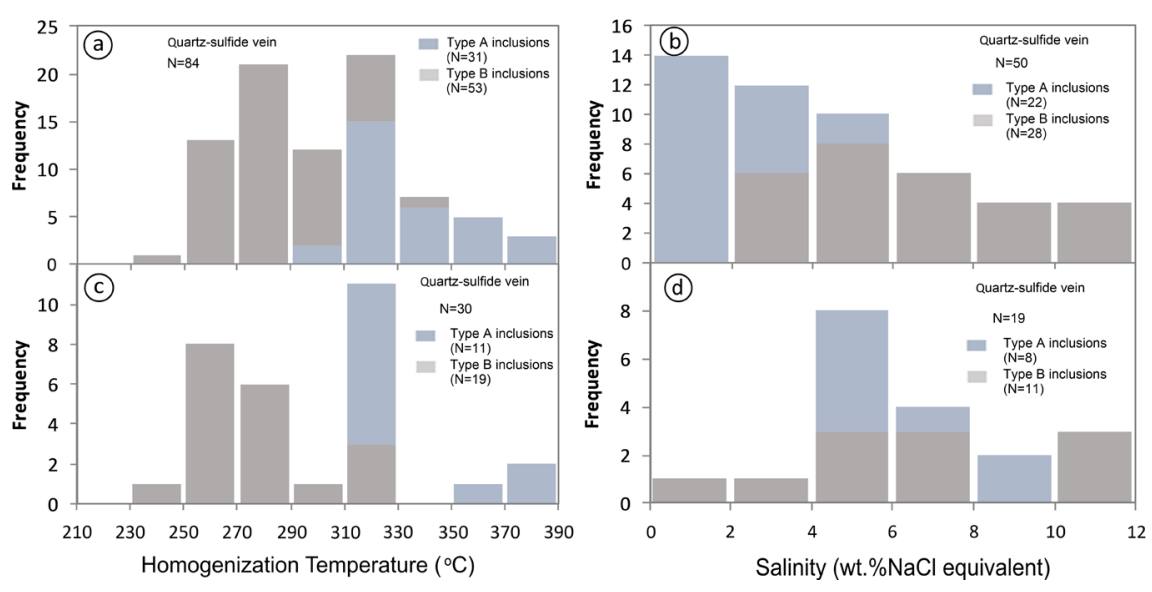

Figure 6. Histograms of total homogenization temperatures $\left(T_{h}\right)$ of primary inclusions and salinities of fluid inclusions in quartz-sulfide vein from the Kunzeik and Zibyaung. (a) Histograms of $\mathrm{T}_{\mathrm{h}}$ of primary inclusions in quartz-sulfide vein from the Kunzeik; (b) Salinities of fluid inclusions in quartz-sulfide vein from the Kunzeik; (c) Histograms of $T_{h}$ of primary inclusions in quartz-sulfide vein from the Zibyaung; and (d) Salinities of fluid inclusions in quartz-sulfide vein from the Zibyaung. Note: $\mathrm{N}=$ total number of fluid inclusions.

temperatures $\left(\mathrm{T}_{\mathrm{h}}\right)$ of Type $\mathrm{B}$ fluid inclusions in vein quartz range from $246^{\circ} \mathrm{C}$ to $312^{\circ} \mathrm{C}(\mathrm{N}=53)$ (Figure $\left.6(\mathrm{a})\right)$. Their final ice melting temperatures $\left(\mathrm{T}_{\mathrm{m} \text {-ice }}\right)$ vary from $-2.1^{\circ} \mathrm{C}$ to $-7.2^{\circ} \mathrm{C}$, which corresponds to salinities between 1.2 and 10.7 wt\% $\mathrm{NaCl}$ equivalent (Figure 6(b)).

\subsubsection{Zibyaung}

The $\mathrm{CO}_{2}$ melting temperatures $\left(\mathrm{T}_{\mathrm{m}-\mathrm{CO} 2}\right)$ of Type A fluid inclusions range from $-57.3^{\circ} \mathrm{C}$ to $-56.8^{\circ} \mathrm{C}$ similar to, or slightly lower than, the triple point of pure $\mathrm{CO}_{2}\left(-56.6^{\circ} \mathrm{C}\right)[15]$. The $\mathrm{CO}_{2}$ phases were totally homogenized to a liquid phase at temperatures $\left(\mathrm{T}_{\mathrm{h}-\mathrm{CO} 2}\right)$ between $28.3^{\circ} \mathrm{C}$ and $30.1^{\circ} \mathrm{C}$. All Type A fluid inclusion were homogenized to a liquid at temperatures $\left(\mathrm{T}_{\mathrm{h}}\right)$ from $305^{\circ} \mathrm{C}$ to $378^{\circ} \mathrm{C}(\mathrm{N}=$ 11) (Figure $6(\mathrm{c})$ ). The melting temperatures of clathrates $\left(\mathrm{T}_{\mathrm{m}-\mathrm{cla}}=4.6^{\circ} \mathrm{C}-7.6^{\circ} \mathrm{C}\right)$ 
yielded salinities between 4.6 and $9.6 \mathrm{wt} \% \mathrm{NaCl}$ equivalent (Figure 6(d)). Homogenization temperatures $\left(\mathrm{T}_{\mathrm{h}}\right)$ of Type $\mathrm{B}$ fluid inclusions of vein quartz range from $242^{\circ} \mathrm{C}$ to $298^{\circ} \mathrm{C}(\mathrm{N}=19)$ (Figure $6(\mathrm{c})$ ). Their final ice melting temperatures $\left(\mathrm{T}_{\mathrm{m} \text {-ice }}\right)$ range from $-0.5^{\circ} \mathrm{C}$ to $-8.1^{\circ} \mathrm{C}$ and correspond to salinities from 0.9 to $11.8 \mathrm{wt} \% \mathrm{NaCl}$ equivalent (Figure 6(d)).

\section{Discussion and Conclusion}

The gold mineralization in the Kyaikhto district is predominately hosted by slate, slaty phyllite, and schist and biotite granite and biotite granodiorite. Gold mineralization in the Kyaikhto district occurred as sheeted veins, massive veins, network veinlets, stockworks, and dissemination. The main ore minerals are sphalerite, galena, chalcopyrite, molybdenite, and pyrite with minor native gold and electrum. From fluid inclusion petrography and microthermometry, two different types of fluid inclusions consisting of aqueous-carbonic fluid (Type A) and aqueous fluid (Type B) are present. These two fluid types have been found to be the most common types in orogenic gold deposits worldwide [18]-[23]. The factors leading to the formation of orogenic gold deposits are numerous and therefore it is difficult to identify a single responsible case for ore precipitation. According to [22] [24], metamorphic devolatilization produces low-salinity fluids that transport gold as reduced sulfur complexes. Ore deposition mechanisms in orogenic gold deposits are usually either fluid-rock reactions, fluid phase separation or fluid mixing with meteoric waters [22] [25]. Moreover, several studies on orogenic gold deposits have perceived ore-mineralizing fluids which were low to moderate temperature, with low salinity, and fluid which was rich in $\mathrm{CO}_{2}$ (e.g., Golden Mile and Kalgoorlie in Western Australia, Victoria in Australia, Motherlode in California and Kolar in India) [19] [20] [21]. As mentioned previously, the $\mathrm{CO}_{2}$-bearing inclusions (Type A) are characterized by relatively higher homogenization temperatures and lower salinities, than the aqueous inclusions (Type B) in both the Kunzeik and Zibyaung. Salinities of Type A fluid inclusions in vein quartz from the Kunzeik are lower than those of gold-bearing quartz vein in the Zibyaung. The salinity of Type B fluid inclusions is the same in both the Kunzeik and Zibyaung. The relationship between $T_{h}$ and salinities of fluid inclusions is shown in (Figure 7). Coexistence of Type A fluid inclusions and Type B fluid inclusions in the same quartz grains has been often interpreted as evidence for fluid immiscibility [15]. However, it is difficult to interpret this phenomenon to be the result of fluid immiscibility in the case of the Kunzeik and Zibyaung. If Type B fluid inclusions resulted from fluid unmixing of an initial Type A fluid inclusion, they would have been saturated with $\mathrm{CO}_{2}$ at entrapment and their homogenization temperatures would represent trapping temperatures. However, Type B inclusions have significantly lower homogenization temperatures $\left(242^{\circ} \mathrm{C}\right.$ to $\left.312^{\circ} \mathrm{C}\right)$ than Type A inclusions $\left(296^{\circ} \mathrm{C}\right.$ to $\left.378^{\circ} \mathrm{C}\right)$, which is difficult to explain because both types of inclusions were broadly contemporaneous [26] [27] (Figure 7). Similar problems have been encountered in 


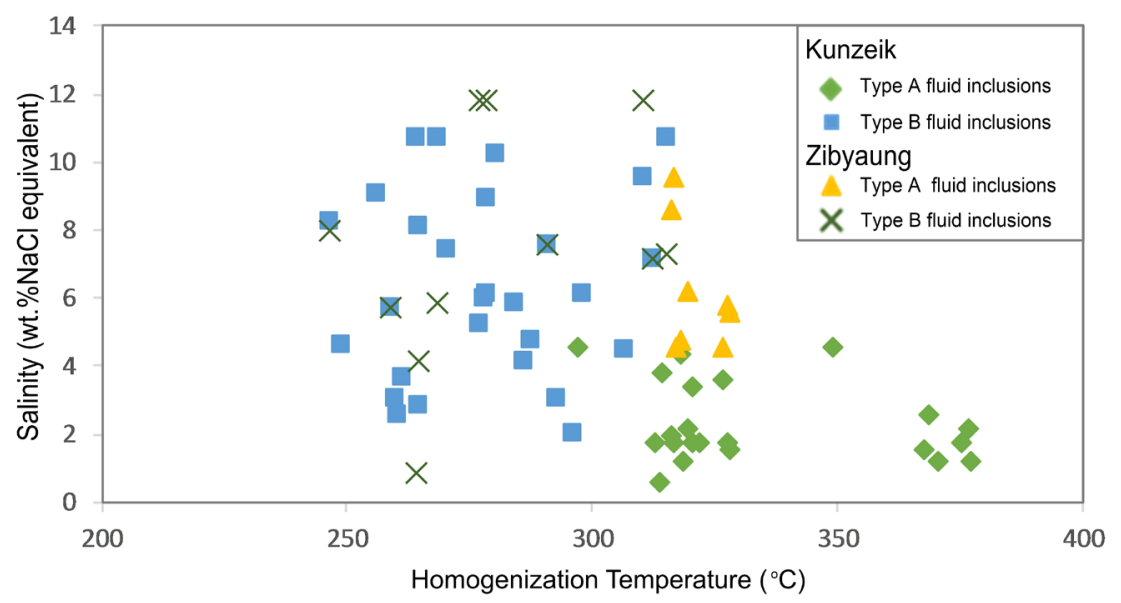

Figure 7. Total homogenization temperature versus salinity diagram for the fluid inclusions of in the quartz-sulfide vein from the Kunzeik and Zibyaung.

orogenic gold deposits where aqueous inclusions and aqueous carbonic fluid inclusions are interpreted as results of fluid unmixing, but the homogenization temperatures of the aqueous inclusions are significantly lower than the trapping temperatures estimated from other geothermometers [26] [27]. Therefore, the homogenization temperatures of Type B inclusions only represent the minimum temperature of trapping; the actual trapping temperatures must be higher than the range of $242^{\circ} \mathrm{C}-312^{\circ} \mathrm{C}$, possibly similar to those of Type A $\left(296^{\circ} \mathrm{C}\right.$ to $\left.378^{\circ} \mathrm{C}\right)$ fluid inclusions [26] [27]. Fluid inclusion studies in the Meyon deposit indicate that ore fluids were $\mathrm{CO}_{2}$-rich, of moderately high temperature $\left(240^{\circ} \mathrm{C}-370^{\circ} \mathrm{C}\right)$ and salinities of $<10 \mathrm{wt} \% \mathrm{NaCl}$ equivalent [9] [10] [11]. The characteristics of the fluid inclusions in these three deposits are similar within the Kyaikhto gold district. The ore-forming fluids of the Kunzeik and Zibyaung which were composed of aqueous-carbonic fluid and aqueous fluid, are different from typical magmatic fluids [19] [23] [28]. The $\mathrm{CO}_{2}$-bearing inclusions are marked by relatively moderate homogenization temperatures $\left(296^{\circ} \mathrm{C}\right.$ to $\left.378^{\circ} \mathrm{C}\right)$ and low salinities (1.6 to $9.6 \mathrm{wt} \% \mathrm{NaCl}$ equivalent), whereas the homogenization temperatures and salinities of aqueous fluid inclusions are relatively low $\left(242^{\circ} \mathrm{C}\right.$ to $\left.312^{\circ} \mathrm{C}\right)$ and low to moderate ( 0.9 to $11.8 \mathrm{wt} \% \mathrm{NaCl}$ equivalent). The fluid inclusion studies reveal that the ore-forming fluids responsible for the Kunzeik and Zibyaung are characterized by abundant $\mathrm{CO}_{2}$-rich fluid inclusions, which are similar features with those of orogenic mineralization systems worldwide [18]-[23]. Thus, the gold mineralization of the Kunzeik and Zibyaung are classified to be orogenic type in the Kyaikhto district.

\section{Acknowledgements}

Sincere thanks are due to the Japan International Cooperation Agency (JICA) SHIGEN NO KIZUNA program for the Ph.D scholarship and financial support. We wish to express our special thanks to Professor Koichiro Watanabe, Professor Akira Imai, Associate Professor Kotaro Yonezu, Department of Earth Re- 
sources Engineering, Kyushu University in Japan for their kind support and encouragement to carry out this research work, advice and reading the manuscript and giving facilities in varies ways.

\section{Conflicts of Interest}

The authors declare no conflicts of interest regarding the publication of this paper.

\section{References}

[1] Mitchell, A.H.G., Htay, N., Ausa, C., Deiparine, L., Khine, A. and Po, S. (1999) Geological settings of gold districts in Myanmar. Proceedings International Congress on Earth Science, Exploration and Mining around the Pacific Rim, Australasian Institute of Mining and Metallurgy, Bali, 10-13 October 1999, 303-309.

[2] Hlaing, M.K., Yonezu, K., Aye, M.T., Myint, A.Z. and Watanabe, K. (2016) Geology and Mineralogical Characteristics of Zibyaung Gold Deposit at Kyaikhto Area, Southern Myanmar. Proceedings of International Symposium on Earth Science and Technology, 403-407.

[3] Mitchell, A.H.G., Chung, S.-L., Oo, T., Lin, T.-H. and Hung, C.-H. (2012) Zircon $\mathrm{U}-\mathrm{Pb}$ Ages in Myanmar: Magmatic-Metamorphic Events and the Closure of a Neo-Tethys Ocean? Journal Asian Earth Science, 56, 1-23.

https://doi.org/10.1016/j.jseaes.2012.04.019

[4] Cobbing, E.J., Pitfield, P.E.J., Darbyshire, D.P.F. and Mallick, D.I.J. (1992) The Granites of the South-East Asian Tin Belt. Overseas Memoir 10, British Geological Survey, $369 \mathrm{p}$.

[5] Myint, A.Z., Yonezu, K., Boyce, A.J., Selby, D., Scherstén, A., Tindell, T., Watanabe, K. and Swe, Y.M. (2018) Stable Isotope and Geochronological Study of the Mawchi Sn-W Deposit, Myanmar: Implications for Timing of Mineralization and Ore Genesis. Ore Geology Reviews, 95, 663-679. https://doi.org/10.1016/j.oregeorev.2018.03.014

[6] Mitchell, A.H.G. (Eds.) (2018) Geological Belts, Plate Boundaries and Mineral Deposits in Myanmar. Myanmar Precious Resources Group, Myanmar and Oxford, United Kingdom, Chapter 1, 3-15.

[7] Mackenzie, M.J. (1999) Report on the Exploration Progress in Block 3/13 for the Period January 1998 to December 1998. Palmer Resources Ltd. Myanmar (Burma) Project, (Unpublished), 1-67.

[8] Swe, Y.M., Aye, C.C. and Zaw, K. (2017) Gold Deposits of Myanmar. In: Barber, A.J., Zaw, K. and Crow, M.J., Eds., Myanmar: Geology, Resources, and Tectonics, Geological Society, London, Memoirs 48, 557-572.

[9] Oo, Z.N. and Zaw, K. (2009) Geology and Mineralization Characteristics of Meyon Gold Deposit, Mon State, Southern Myanmar. Proceedings of 11 th Regional Congress on Geology, Mineral and Energy Resources of Southeast Asia (GEOSEA), Kuala Lumpur, 8-10 June 2009, 32.

[10] Oo, Z.N., Zaw, K. and Mernagh, T. (2010) Geological Setting and Nature of Mineralization at Meyon Gold Deposit, Mon State, Myanmar. 13th Quadrennial International Association on Genesis of Ore Deposits (IAGOD) Symposium, Adelaide, 6-9 April 2010, CD-ROM.

[11] Oo, Z.N. and Zaw, K. (2015) Geology and Mineralization Characteristics of Meyon Gold Deposit, Mon State, Southern Myanmar. Society of Economic Geologists 
Conference, Hobart, 27-30 September 2015, CD-ROM.

[12] Mitchell, A.H.G., Ausa, C., Deiparine, L., Hlaing, T., Htay, N. and Khine, A. (2004) The Modi Taung-Nankwe Gold District, Slate Belt, Central Myanmar: Mesothermal Veins in a Mesozoic Orogen. Journal Asian Earth Science, 23, 321-341. https://doi.org/10.1016/S1367-9120(03)00138-X

[13] Barber, A.J., Crow, M.J. and Zaw, K. (Eds.) (2017) Myanmar: Geology, Resources, and Tectonics. Geology Society of London, Memoir 48, 687-712. https://doi.org/10.1144/M48.31

[14] Zaw, K. and Meffre, S. (2014) Tectonics and Metallogeny of Mainland SE Asia-A Review and Contribution. Special Issue on Tectonics and Metallogeny of Mainland SE Asia. Gondwana Research, 26, 5-30. https://doi.org/10.1016/j.gr.2013.10.010

[15] Roedder, E. (1984) Fluid Inclusions. Reviews in Mineralogy, 12, 644 p. https://doi.org/10.1515/9781501508271

[16] Bodnar, R.J. (1993) Revised Equation and Table for Determining the Freezing Point Depression of $\mathrm{H}_{2} \mathrm{O}-\mathrm{NaCl}$ Solutions. Geochimica et Cosmochimica Acta, 57, 683-684. https://doi.org/10.1016/0016-7037(93)90378-A

[17] Collins, P.L.F. (1979) Gas Hydrates in $\mathrm{CO}_{2}$-Bearing Fluid Inclusions and Use Freezing Data for Estimation of Salinity. Economic Geology, 74, 1435-1444. https://doi.org/10.2113/gsecongeo.74.6.1435

[18] Diamond, L.W. (2001) Review of the Systematics of $\mathrm{CO}_{2}-\mathrm{H}_{2} \mathrm{O}$ Fluid Inclusions. $\mathrm{Li}$ thos, 55, 69-99. https://doi.org/10.1016/S0024-4937(00)00039-6

[19] Goldfarb, R.J., Baker, T., Dube, B., Groves, D.I., Hart, C.J.R. and Gosselin, P. (2005) Distribution, Character, and Genesis of Gold Deposits in Metamorphic Terranes. In: Hedenquist, J.W., Thompson, J.F.H., Goldfarb, R.J. and Richards, J.P., Eds., Economic Geology 100 th Anniversary Volume, Society of Economic Geologists Inc., Littleton, 407-450.

[20] Groves, D.I., Goldfarb, R.J., Gebre-Mariam, M. and Hagemann, S.G. (1998) Orogenic Gold Deposits: A Proposed Classification in the Context of Their Crustal Distribution and Relationship to Other Gold Deposit Types. Ore Geology Reviews, 13, 7-27. https://doi.org/10.1016/S0169-1368(97)00012-7

[21] Groves, D.I., Goldfarb, R.J., Robert, F. and Hart, C.J.R. (2003) Gold Deposits in Metamorphic Belts: Overview of Current Understanding, Outstanding Problems, Future Research, and Exploration Significance. Economic Geology, 98, 1-29.

[22] Ridley, J.R. and Diamond, L.W. (2000) Fluid Chemistry of Lode-Gold Deposits and Implications for Genetic Models. In: Hagemann, S.G. and Brown, P., Eds., Reviews in Economic Geology. Gold in 2000, Society of Economic Geologists, Vol. 13, 141-162.

[23] Wilkinson, J.J. (2001) Fluid Inclusions in Hydrothermal Ore Deposits. Lithos, 55, 229-272. https://doi.org/10.1016/S0024-4937(00)00047-5

[24] Phillips, G.N. and Powell, J.K. (1993) Link between Gold Provinces. Economic Geology, 88, 1084-1098. https://doi.org/10.2113/gsecongeo.88.5.1084

[25] Hagemann, S. and Cassidy, K. (2000) Archean Orogenic Lode Gold Deposits. Reviews in Economic Geology, 13, 9-68.

[26] Chi, G.X. and Xue, C.J. (2011) Abundance of $\mathrm{CO}_{2}$-Rich Fluid Inclusions in a Sedimentary Basin-Hosted Cu Deposit at Jinman, Yunnan, China: Implications for Mineralization Environment and Classification of the Deposit. Mineralium Deposita, 46, 365-380. https://doi.org/10.1007/s00126-011-0337-8

[27] Robert, F. and Kelly, W.C. (1987) Ore-Forming Fluids in Archean Gold-Bearing 
Quartz Veins at Sigma Mine, Abitibi Greenstone Belt, Quebec, Canada. Economic Geology, 82, 1464-1482. https://doi.org/10.2113/gsecongeo.82.6.1464

[28] Audétat, A., Pettke, T., Heinrich, C.A. and Bodnar, R.J. (2008) The Composition of Magmatic-Hydrothermal Fluids in Barren and Mineralized Intrusions. Economic Geology, 103, 877-908. 